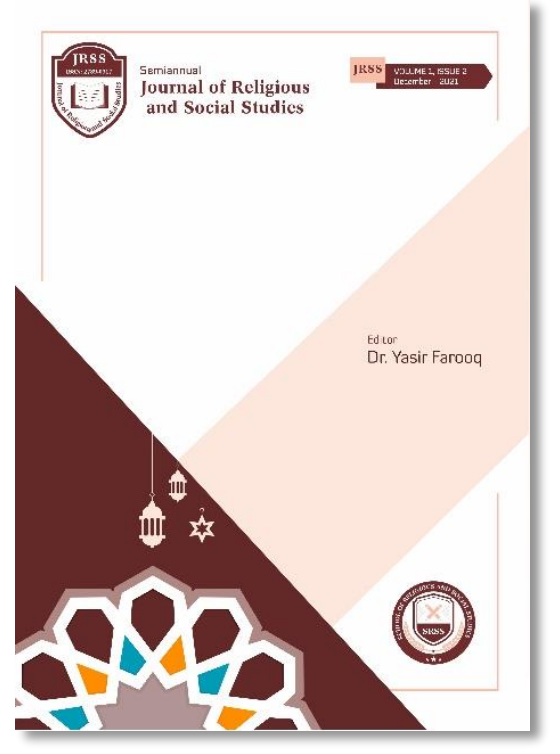

Journal of Religious and Social Studies

http://ejrss.com/index.php/jrss

ISSN (Print): 2789-0317

ISSN (online): 2789-0325

School of Religious and Social Studies,

Faisalabad (38000), Pakistan.

\title{
Religious Concerns of Dowry and Marriage Gifts Regarding Determination of their Limits: Study of Malaysian law
}

Ahmad Haziq Haikal Kamal, Miszairi Sitiris, and Mohamad Afiq Razali To cite this article:

Ahmad Haziq Haikal Kamal, Miszairi Sitiris, and Mohamad Afiq Razali. "Religious Concerns of Dowry and Marriage Gifts Regarding Determination of their Limits: Study of Malaysian law." Journal of Religious and Social Studies 1, no. 2 (2021): 37-50.

DOI: https:// doi.org/10.53583/jrss04.0102.2021

至望 Published online: 30 September 2021

Submit your article to JRSS

: View this issue

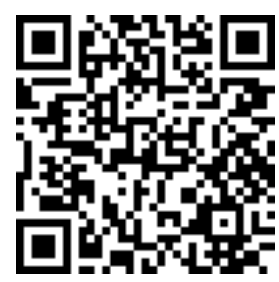

open access

Full Terms \& Conditions of access and licensing can be found at: http:/ / ejrss.com/index.php/jrss/policies

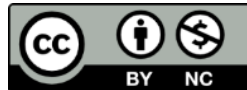




\title{
RELIGIOUS CONCERNS OF DOWRY AND MARRIAGE GIFTS REGARDING DETERMINATION OF THEIR LIMITS: STUDY OF MALAYSIAN LAW
}

\author{
Ahmad Haziq Haikal Kamal ${ }^{1}$, Miszairi Sitiris ${ }^{2}$, and Mohamad Afiq Razali ${ }^{3}$
}

\begin{abstract}
In 2010, the Islamic religious department of a state in Malaysia issued a fatwa, which ruled that the dowry rate in the state would be regulated at a minimum value of RM 300, with no indication of a maximum amount. In this instance, the community appears to be more concerned with the function of the provision of gift money, which is used solely to fund wedding expenses, rather than with the potential of dowry, which plays a more significant role for women. While this research does not challenge the fatwa's decision, it does attempt to elucidate the issue of determining the minimum dowry rates from the perspective of figh and the Islamic Religious Administration Enactment. The library technique and inductive reasoning are by far the most often used ways of data collection by the author. On the whole, dowry has no specific limit while there are opinions of scholars on this, the setting of this dowry restriction, in particular, was never specified by Islām. People in the community misinterpret the meaning of the minimum and maximum limits, which leads to the low dowry and the high importance given to the provision of gift money.
\end{abstract}

Keywords: Dowry, Gift Money, Islamic Law, Legislative, Islamic Jurisprudence, Malaysia.

\section{PRELUDE}

The Islamic tradition of providing a dowry to women as a show of respect and glory before entering the realm of marriage is well-established. The gift of dowry is sometimes 
interpreted as a way for a husband to convey his feelings of love and affection for his wife. The Qur'ān states:

\section{"And give the women [upon marriage] their [bridal] gifts graciously"4}

The term 'and give' employed in this passage is a command word, and it suggests that dowry is required in a marriage ceremony. Dowry is required as a result of the marital contract or sexual encounters between the couple. ${ }^{5}$ It also goes by a variety of names, including Sadāq, Nihlah, Farīdah, Hibah, 'Ajar, Tawl, 'Uqr, and 'Alāiq,' all of which relate to the same meaning and importance as dowry in terms of meaning and significance.

Dowry is classified into two types: Musammā (Mentioned and agreed between both) and Mithl (Traditionally understood from bride's family). ${ }^{7}$ Musammā is the more traditional form where is a dowry that is agreed upon by both couples, whereas Mithl is a dowry that is decided in quantity, shape, and form based on the value of the dowry of the lineage of the father's wife's relatives, with the amount, shape, and type chosen by the father's wife's relatives. ${ }^{8}$

This clause is viewed as improving the dignity and standing of women and is regarded as an indisputable privilege reserved for them. As a result, neither her father nor her husband has the authority to take it without first obtaining his consent. While it is believed that providing dowry rather than the provision of gift money will ensure this exclusive privilege ${ }^{9}$, reality demonstrates differently. A misunderstanding of the terms dowry and provision of gift money has created confusion among the bride's parents, who believe that provision of gift money must be paid in the same manner as dowry. ${ }^{10}$

\section{Al-Qur'an 4:4.}

Wahbah al-Zuhailī, Al-Figh al-Islāmī Wa Adillatuhu (Damascus: Dār al-Fikr, n.d.), 6:759.

Al-Khațīb Al-Syarbīnī, Mughnī al-Muhtāj Ilā Ma rifatì Ma 'ānī Alfāz al-Minhāj (Beirut: Dār al-Kutub al-'Ilmiyyah, 1994), 367.

'Umar Sulaimān al-Ashqar, Aḥkām al-Zawāj Fì Dau'i al-Kitāb Wa al-Sunnah (Jordan: Dār al-Nafā' is, 1997), 261.

Mușțafā al-Khin, Muṣțafā al-Bughā and 'Ali al-Sharbajī, al-Figh al-Manhajī 'Alā Mazhab alImām al-Shāfi' 'i (Damascus: Dār al-Qalam, 2013), 76.

Ali Hasbi Hj Muh, and Raihanah Hj Azahari, "Objektif Syariah Dalam Pemberian Mahar," Jurnal Fiqh, no. 10 (2013): 68, https://doi.org/10.22452/fiqh.vol10no1.3

Rifqah Begum Mohammad Syamin, Qad̄àyā al-Mahar Wa Hadāyā Fì Wilāyah Malākā (Masters diss.: International Islamic University Malaysia, 2012), 147. 
This demonstrates that society, in comparison to the provision of gift money, is still unable to comprehend the critical significance of dowry in ensuring married women's survival. ${ }^{11}$

Due to the presence of two factors in this marriage, an imbalance exists between the rates of dowry and provision of gift money, with one exceeding the other, prompting the state of Selangor to establish a minimum dowry limit. ${ }^{12}$ This is also interpreted as a violation of women's ownership rights, as the provision of gift money is not the exclusive property of the dowry. This is because of the effect and influence of marriage-related rituals and traditions that are still observed and accepted by the majority of people today. $^{13}$

\section{MUSLIM SCHOLARS' VIEWS ON THE DETERMINATION OF DOWRY}

\section{RATES}

Islām has prescribed the payment of dowry to the wife without imposing any restrictions on the amount to be paid or the pace at which it should be paid. Dowry can be made up of anything that is precious and can be sold or rented for a good amount of money. The value is expressed in the form of 'Ain, debt, or advantages, which might be little or large, in the shape of money or a house, or in the form of teaching the Qur'ān to the wife. When it comes to dowry, neither the Qur'ān nor the Sunnah guides how much is considered sufficient. Depending on a person's status and aptitude, some are blessed by Allah almighty with a great deal of sustenance, and then some live in poverty and rely on others.

As a result, scholars have agreed that there is no maximum rate for dowry and that the determination of dowry is depending on the agreement between two parties, whether the amount is in the tens of thousands of dollars or the tens of thousands. This

$11 \quad$ Ali and Azahari, Objektif Syariah, 71.

12 Kemalia Othman, "Mas Kahwin Selangor Dinaik Kepada RM300," accessed August 14, 2021, https://www.mstar.com.my/lokal/semasa/2009/12/10/mas-kahwin-selangor-dinaikkepada-rm300. 
is predicated on the absence of proof regarding the restriction or injunction setting the maximum rate for dowry. It is stated in the agreement that the scholars have decided that there is no maximum limit for dowry. ${ }^{14}$

Despite this, there is still debate among Muslim scholars as to the appropriate level of dowry to be demanded as a bare minimum. The following are some of the differences of opinion among Muslim scholars on the minimum amount of dowry that should be paid:

First opinion: the Hanafi and Mālikì schools of thought believe that there is a minimum amount of dowry that should be paid. This group believes that the amount of dowry provided by males should be kept to a bare minimum. For the Hanafi sect, the minimal amount of dowry is not less than ten dirhams, and any type of gift with a value of 10 dirhams ${ }^{15}$ is considered acceptable (29.75 grams of gold) ${ }^{16}$. According to the Mālikì sect, the minimum amount of dowry is one-quarter of an ounce of gold or three dirhams of pure silver metal $(8,925 \text { grams of gold })^{17}$, or anything of comparable worth ${ }^{18}$. The Qur'ān states:

"All others are lawful, provided you seek (them in marriage) with Mahr (bridal money given by the husband to his wife at the time of marriage) from your property, desiring chastity, not committing illegal sexual intercourse" 19

According to Imām al-Kāsānì, Allah almighty has stated that the dowry must be from anything that is deemed property based on the verse (from your property), whereas grains

'Abdullah Ibn Aḥmad Ibn Muhammad Ibn Qudāmah, al-Mughnī (Cairo: Maktabah alQāhirah, 1968), 209.

Abū Bakar Ibn Mas' ūd Ibn Aḥmad al-Kāsānī, Badā'i ' al-Sanā'i ' Fī Tartīb al-Sharā'i ' (Beirut: Dār al-Kutub al-'Ilmiah, 1986), 274.

Dian Ramadhan and Farah Ihza Fauzia Balqis, "Pandangan Mazhab Hanafi Dan Maliki Terhadap Jumlah Kadar Mahar Pada Akad Nikah," JAWI 3, no. 1 (2020), 42. https://dx.doi.org/10.24042/jw.v3i1.7036.

18 Muhammad Ibn Aḥmad Ibn Rushd, Bidāyah al-Mujtahid Wa Nihāyah al-Muqtașid (Cairo: Dār al-Hadīth, 2004), 45. 
of seeds from plants and dāniq $(1 / 6 \text { Dirham })^{20}$ are exempt from the definition of property. As a result, it cannot be used as a dowry. ${ }^{21}$ It may be understood through al-Imām's which defines the worth of little and much. ${ }^{22}$ They also quote a hadith which the Prophet Muhammad (PBUH) is said to have said:

"No dowry is less than 10 dirhams"23

This hadith is contrasted (Qiās) to the unit of measure that allows for the imposition of a thief's penalty, which is 10 dirhams in value. This indirectly demonstrates the status of women in terms of religion, as well as the fact that the placement of dowry has a substantial impact on women's economic well-being. ${ }^{24}$

Second opinion: The Shäfi ' $\bar{\imath}$ and Hanbali schools of thought believe that the minimum dowry limit should not be fixed at a rate. ${ }^{25}$ As a result, everything regarded precious and valued, no matter how little or how much, can be used as a dowry. This is founded on the idea that anything that is deemed valuable for sale can be used as a dowry. ${ }^{26}$ The legality of the dowry supplied is decided by the value of the gift itself, not by how much or how little is given. It is acceptable to utilise as dowry as long as it is recognised by Islamic law as something worthy of usage.

It is supported by the Qur'ān verse 24, which does not set a rate for dowry; as a result, it is implemented based on its universality, which is supported by the evidence of the verse. Also cited is the hadith related by Sahl Ibn Sa'ad, which states that when a companion presented the Prophet Muhammad (PBUH) with a gift of an iron ring, the Prophet Muhammad (PBUH) responded:

Aḥmad Ibn 'Ali Ibn Hajar al-'Asqalānī, Fath al-Bārī Sharh Ṣaḥị̣ al-Bukhārī (Beirut: Dār al-Ma 'rifah, 1959), 194.

21 al-Kāsānī, Badā'i ' al-Șanā 'i Fì Tartīb al-Sharā 'i ', 2:275.

22 al-Kāsānī, Badā' $i$ ' al-Șanā 'i' Fì Tartīb al-Sharā 'i', 2:276.

'Ali Ibn 'Umar al-Dārquṭni, Sunan al-Dārquțni (Beirut: Muassasah al-Risālah, 2004), 4: 360 .

24 Ramadhan and Balqis, Pandangan Mazhab, 50.

25 'Ali Ibn Muhammad al-Māwardī, al-Hāwī al-Kabīr (Beirut: Dār al-Kutub al- 'Ilmiah, 1999), 9:397; 'Abd al-Raḥman Ibn Qudāmah, al-Sharh al-Kabìr 'Alā Matni al-Muqni ' (Beirut: Dār al-Kutub al-'Arabī Li al-Nashri Wa al-Tauzi', n.d.), 8:4.

26 Muhammad al-Zuhailī, al-Mu 'tamad Fi al-Figh al-Shāfi 'ī (Damascus: Dār al-Qalam, 2011), 4:113. 
"Give her (dowry) even if it is only an iron ring" 27

According to the preceding hadith, the Prophet Muhammad (PBUH) streamlines the marriage arrangements of his companions who wish to be married, serving as a guide for Muslims. It is revealed in the hadith that the dowry is a type of iron ring, which demonstrates that the dowry is proportionate to the abilities of the prospective spouse.

Based on the arguments advanced by Muslim scholars about the minimum amount of dowry that should be paid, the author, with a deep feeling of humility, agrees with the view advanced by the Shäfi $i$ and Hanbali sects that there is no such thing as a minimum amount of dowry that should be paid. Everything valuable and regarded property from an Islamic perspective, in some form or another, can be utilised as dowry.

The obligatory gift, which must be provided by the man voluntarily and without the expectation of receiving something in return, is a gesture of love and duty on the part of the husband toward his wife. Instead of serving as a gesture of reciprocity, this present is intended just to promote peace and harmony between husband and wife. As a result, lowering the dowry rate to a bare minimum is regarded as a failure to achieve that purpose. This article asserts that fiqh scholars' opinions on dowry rates are valid since they are perceived to accomplish the objective for which dowry was originally intended by the fiqh scholars themselves.

\section{DETERMINATION OF MINIMUM RATE FOR DOWRY ACCORDING TO THE ADMINISTRATION OF THE RELIGION OF ISLĀM ENACTMENT, STATE OF SELANGOR}

In accordance with the Selangor Islamic Religious Administration Enactment 2003, a fatwa was issued by the state mufti's office on December 31, 2009, and it was gazetted on January 1, 2010. The following decisions were made on the instruction of the chairman of the Selangor fatwa committee: $7: 6$ 
"Set a dowry value rate minimum of RM300 for virgins or widows, with no maximum limit. If the man makes a monetary gift, it is considered dowry" 28

Following the fatwa, the dowry rate in Selangor has raised by RM220 for virgins and by RM260 for widows since 2010, compared to the previous rates of RM80 and 40, respectively ${ }^{29}$. According to Datuk Mohamed Khusrin Munawi ${ }^{30}$, an increase of RM220 and RM260 is considered as an effort to enhance the position of women in the state ${ }^{31}$. He also stressed the importance of the increase. Additionally, this increase is being implemented to calibrate the rate under current economic changes as well as to standardise the amount of dowry paid regardless of whether the bride is a virgin or a widow ${ }^{32}$.

Despite the growth in the value of the dowry rate, it cannot be seen as a means of elevating the status of women since it is too little and insignificant in comparison to the provision of gift money. It also does not celebrate the present quality of life in this developed state. When the dowry value is established at a minimum of RM300, it is considered improper when the provision of gift money is greater, even in the tens of thousands of ringgit, as if the importance of custom outweighs the relevance of Shari'ah, it is considered inappropriate. In general, this can be observed in the table below, which indicates the minimum dowry amount and the rate of provision of gift money value according to the level of education in Selangor as follows: Islamic Religious Administration Enactment (The State of Selangor) 2003, 48(6), 63: 3.

29 Kemalia Othman, Mas Kahwin Selangor Dinaik Kepada RM300.

30 Director of the Selangor Islamic Religious Department (JAIS)

31 Kemalia Othman, Mas Kahwin Selangor Dinaik Kepada RM300.

Ibid.
} 


\section{Selangor}

The vast majority of individuals
Virgin

RM 300
Widow

RM 300

Table 1: Dowry Rates in the State of Selangor Starting in 2010. ${ }^{33}$

\begin{tabular}{|l|c|c|}
\hline The level of education & Minimum & Maximum \\
\hline UPSR and PMR & RM 2,000 & RM 4,000 \\
\hline SPM & RM 4,000 & RM 8,000 \\
\hline STPM and DIPLOMA & RM 8,000 & RM 12,000 \\
\hline Bachelor's Degree & RM 12,000 & RM 15,000 \\
\hline Master's Degree & RM 15,000 & RM 20,000 \\
\hline Doctor of Philosophy & RM 20,000 & RM 30,000 \\
\hline
\end{tabular}

Table 2: Provision of Gift Money Rates in the State of Selangor. ${ }^{34}$

If the lowest rate for dowry is RM300, the lowest rate for the provision of gift money is RM 2000, indicating that the sending of gift money is viewed as favouring custom. This is due to society's custom of using gift money to cover wedding costs such as a wedding feast ${ }^{35}$. According to the author, society only considers the specified rate since it is a necessary ritual, as well as simply fulfilling the criteria of the marital procedure, without being aware of the lack of a maximum dowry limit. As a result of the RM300 dowry rate granted to the bride, substantial provision of gift money are provided by

Kemalia Othman, Mas Kahwin Selangor Dinaik Kepada RM300.

Ahmad Hafizan Ariffin and Maimun Aqsha Lubis, "Mahar," in 10TH International Workshop and Conference of Asean Studies In Islamic and Arabic Education Science And Technology (Faculty of Education: Univerisiti Kebangsaan Malaysia, 2017), 110.

Husin Azahari, and Rahman, Perbelanjaan Perkahwinan, 110. 
agreement and demand from the bride's family. ${ }^{36}$ Therefore, there is a need to return to the requirement of a minimum dowry limit to balance out the excessively high rate of gift money and restore the rights of women to the status they earned.

Furthermore, the fatwa given makes it plain that if a man sends money to his wife, it would be considered dowry and will be taxed accordingly. Thus, the provision of gift money received during the marriage contract would be regarded as dowry and will be mentioned jointly with the Ijjāb o Qubūl nikāh/ceremony. Khusrin further underlined the importance of this issue by stating that the phrase "provision of gift money" is no longer used in the state since it is already incorporated in the dowry agreement. ${ }^{37}$

The practice of today's culture, however, leads them to believe that the provision of gift money is an integral component of the marriage. This is due to the culture and tradition of the community, which is still believed to adhere to the custom of marriage, which requires that the provision of gift money be made in advance of the creation of the wedding ceremony. ${ }^{38}$ As a result, we can observe that there are still many people in society who are unwilling to allow the provision of gift money to be coupled with a dowry to assist the business of hosting a wedding reception.

Although this fatwa has been in print for over 11 years, the author believes that it is not being distributed widely enough to the general population. This is because the present trend indicates that the provision of gift money is still being practised and that the pace of increase is growing year after year. As a result, males are burdened with the responsibility of providing the mandatory dowry while also providing provision of gift money, the amount of which is chosen by the woman's family based on a variety of criteria. $^{39}$

A minimal dowry fee, according to JAIS's Director, is established to alleviate the financial strain associated with wedding feasts. ${ }^{40}$ The wedding ceremony is not done by a single party, but by both the groom and his bride. A wedding feast is also held as a

36 Syamsyida Hj. Mohd. Shah, Al-'Arāf al-Malāyuwìnyah Fī Muqaddimah al-Zawāj Fī Mālìziyā (Masters diss.: International Islamic University Malaysia, 2005), 77. Kemalia Othman, Mas Kahwin Selangor Dinaik Kepada RM300.

38 Ariffin and Lubis, Mahar, 104.

39 Syamsyida, al- 'Arāf al-Malāyuwìyyah, 77.

40 Kemalia Othman, Mas Kahwin Selangor Dinaik Kepada RM300. 
sign of the wedding announcement, but only the groom spends a lot of money on the wedding feast. This is viewed as a weight of marriage that must be faced by men who wish to start a family with their spouse, and as a result, it becomes a contributing factor to the postponement of marriage. ${ }^{41}$

Therefore, the minimum rate for dowry should, in the opinion of the author, be adjusted to a fair rate to balance the value of the provision of gift money that must be provided. This is because society believes that the bare minimum is what must be provided, as though the rate of RM300 is required since it is set by the government, but what is intended is the very minimum in terms of dowry payments. In the opinion of Missouri, the imposition of this minimal restriction was necessary to maintain a balance in the provision of gift money rate so that it does not become a burden on the men and to prevent the accumulation of excessive dowry. ${ }^{42}$

When it comes to the provision of gift money rates, the fact is that they may range from thousands of ringgit to hundreds of thousands of ringgit. This is especially true when it comes to the amount of money paid as dowry, which is viewed as surpassing the custom when compared to the Shari'ah. To avoid making the provision of gift money a burden and a tough task for the males, we have a legitimate reason to give priority to Shari'ah above custom. Setting the rate of provision of gift money at a higher rate than the dowry will be tough for males and will be in direct contradiction to Qur'ān:

"Allah intends for you ease and does not intend for you hardship"43

This can be supported by a hadith from ' $\bar{A}$ 'ishah $(R A W)$, which can be utilised as guidance in this case. The Prophet Muhammad (PBUH) said the following:

"The most blessed wedding is the one with the least expenses" 44

41 Siti Zaleha Ibrahim, Phayilah Yama, and Hasliza Talib. “Hantaran," in e-Prosiding Persidangan Antarabangsa Sains Sosial Dan Kemanusiaan (Kajang: International Islamic University College Selangor, 2018), 535. Usrah al-Islāmiah Bi Mālìziyā Namūzajan (PhD diss.: International Islamic University Malaysia, 2008), 191.

43 Al-Qur'an 2:185.

44 Ahmad Ibn Muhammad Ibn Hanbal, Al-Musnad (Cairo: Maktabah al-Risālah, 2001), 42:54 
According to the aforementioned hadith, it is obvious that a marriage that is not founded on a large amount of dowry would be blessed in the marriage relationship. If the dowry derived from the Qur'ann and Sunnah is not worth the rate alone, let alone if the provision of gift money derived from tradition and culture is given at a fair rate that does not burden the guy. For those who can afford it, marriage is a sacred and cherished relationship. As a result, the establishment of the minimal limit of RM300, as well as the high provision of gift money rate, do not appear to accomplish the hadith's stated objective.

\section{CONCLUSION}

Dowry is a legally required gift from the husband and is reserved exclusively for the wife's use. Depending on the circumstances, dowry can be given in a variety of forms, including money and property such as a home, land, or the Qur'ann, as well as anything else that is deemed valuable and considered to be property from an Islamic perspective. If a piece of property is considered valuable in terms of Islamic law and may be exchanged, it is permitted to be used as dowry, and this is the primary indicator that serves as the standard for the practice. The absence of a restriction on the highest amount of dowry has been agreed upon by Muslim scholars, although they disagree on the amount of dowry that should be paid as a minimum. Islamic scholars, including those from the Hanafi and Mãliki sects, have expressed opinions on the minimum amount of dowry that should be paid, although Islām has never stated a minimum or maximum amount of dowry that should be paid.

The fatwa issued by the Mufti's office in Selangor is also regarded as an effort to elevate the dignity of women by establishing a minimum dowry limit of RM300 to serve as a guide to society, according to some observers. However, given the image of the society, which still places a higher value on the provision of gift money than dowry, the reality is quite the reverse. Moreover, the setting of the dowry rate at the bare minimum causes confusion among the community as to whether this is the rate at which dowry should be given, even though the fatwa issued explicitly states that there is no setting for the maximum limit, which indicates that dowry can be given more than RM300.

Because of this, the author suggests that the setting of this minimum limit be reviewed, with a reasonable amount being established in recognition of the current 
economic situations, and that efforts be intensified to disseminate and explain the fatwa to the public through religious programmes and other means of $d a$ 'wah. No attempt has been made here to call into question the validity of the fatwa issued by religious authorities after considering all available evidence, but rather an attempt has been made to raise awareness and to improve and justify the practice so that dowry is seen as something that enhances the dignity and glory of women, rather than something that diminishes it. According to the author, if this minimal restriction is raised at an acceptable rate, it will undoubtedly provide relief to women while also providing room for males.

Indeed, the provision of large dowry is regarded as more significant than the provision of gift money since the provision of dowry is drawn from the Qur'ān and Sunnah, and the offender will be awarded a great reward for following Allah order. Islām, on the other hand, continues to advocate for the simplification of marriage-related matters to relieve the burden placed on the couple that wants to be married 
Journal of Religious and Social Studies

December-2021, Vol.: 1, Issue: 2, PP: 37-50

https://doi.org/10.53583/jrss04.0102.2021

\section{BIBLIOGRAPHY}

Al-Ashqar, 'Umar Sulaimān. Aḥkām al-Zawāj Fì Dau'i al-Kitāb Wa al-Sunnah. Jordan: Dār al-Nafā' is, 1997.

Al-'Asqalānī, Aḥmad Ibn 'Ali Ibn Ḥajar. Fath al-Bārì Sharh Ṣaḥị̣ al-Bukhārī. Beirut: Dār al-Ma rifah, 1959.

Al-Bukhārī, Muḥammad Ibn Ismā il. Șaḥịh al-Bukhārī. Beirut: Dār Ṭawq al-Najāh, 2001.

Al-Dārquṭni, 'Ali Ibn 'Umar. Sunan al-Dārquțin. Beirut: Muassasah al-Risālah, 2004.

Ali, Hasbi Hj, and Raihanah Hj Azahari. “Objektif Syariah Dalam Pemberian Mahar." Jurnal Fiqh, no. 10 (2013): 57-76, https://doi.org/10.22452/fiqh.vol10no1.3.

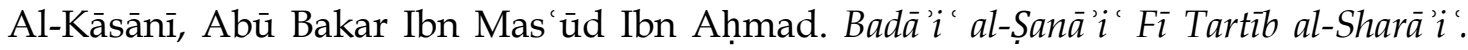
Beirut: Dār al-Kutub al-'Ilmiyyah, 1986.

Al-Khin, Mușțafā, Al- Bughā, Mușțafā, al-Sharbajī, 'Ali. al-Fiqh al-Manhajī 'Alā Mazhab al-Imām al-Shāfi 'ì. Damascus: Dār al-Qalam, 2013.

Al-Māwardī, 'Ali Ibn Muhammad, al-Hâàì al-Kabìr. Beirut: Dār al-Kutub al-'Ilmiah, 1999.

Al-Syarbīnī, Al-Khațīb. Mughnī al-Muḥtāj Ilā Ma rifatī Ma 'ānī Alfāẓ al-Minhāj. Beirut: Dār al-Kutub al-'Ilmiyyah, 1994.

Al-Zuhailī, Muhammad. al-Mu'tamad Fi al-Figh al-Shāfi ì. Damascus: Dār al-Qalam, 2011.

Al-Zuhailī, Wahbah. al-Fiqh al-Islāmī Wa Adillatuh. Damascus: Dār al-Fikr, n.d.

Ariffin, Ahmad Hafizan, and Maimun Aqsha Lubis. "Mahar," in 10TH International Workshop And Conference Of Asean Studies In Islamic And Arabic Education Science And Technology, 103-112. Faculty of Education: Universiti Kebangsaan Malaysia, 2017.

Bin Sitiris, Miszairi. “al-Huqūq al-Māliah Lil al-Muțallaqah Fō al-Fiqh al-Islāmī Wa Qawānìn al-Usrah al-Islāmiah Bi Māliziyā Namūzajan." Ph.D. diss., International Islamic University Malaysia, 2008.

https://www.mstar.com.my/lokal/semasa/2009/12/10/mas-kahwinselangor-dinaik-kepada-rm300.

Husin, Syh Noorul Madihah Syed, Raihana Hj Azahari, and Asmak Ab Rahman. "Perbelanjaan Perkahwinan Bagi Masyarakat Melayu: Analisis Literatur." Jurnal Fiqh, no. 13 (2016): 23-56, https:/ / doi.org/10.22452/fiqh.vol13no1.2.

Ibn Hanbal, Aḥmad Ibn Muhammad. Musnad al-Imām Aḥmad Ibn Hanbal. Beirut: Maktabah al-Risālah, 2001. 
Journal of Religious and Social Studies

December-2021, Vol.: 1, Issue: 2, PP: 37-50

https://doi.org/10.53583/jrss04.0102.2021

Ibn Qudāmah, 'Abdullah Ibn Aḥmad Ibn Muhammad. al-Mughnì. Cairo: Maktabah al- Qāhirah, 1968.

Ibn Qudāmah, 'Abd al-Raḥman. al-Sharh al-Kabìr 'Alā Matni al-Muqni'. Beirut: Dār alKutub al-'Arabī Li al-Nashri Wa al-Tauzi', n.d.

Ibn Rushd, Muhammad Ibn Aḥmad. Bidāyah al-Mujtahid Wā Nihāyah al-Muqtașid. alQāhirah: Dār al-Hadīth, 2004.

Ibrahim, Siti Zaleha, Phayilah Yama, and Hasliza Talib. "Hantaran." in e-Prosiding Persidangan Antarabangsa Sains Sosial Dan Kemanusiaan (Kajang: International Islamic University College Selangor, 2018), 534-540.

Islamic Religious Administration Enactment (The State of Selangor) 2003.

Othman, Kemalia. “Mas Kahwin Selangor Dinaik Kepada RM300.” Mstar, 14 August 2021.

Ramadhan, Dian, and Farah Ihza Fauzia Balqis. "Pandangan Mazhab Ḥanafī Dan Maliki Terhadap Jumlah Kadar Mahar Pada Akad Nikah." JAWI 3, no. 1 (2020): 41-58, https:/ / dx.doi.org/10.24042/jw.v3i1.7036.

Shah, Syamsyida Hj Mohd. "al-'Arāf al-Malāyuwīyyah Fì Muqaddimah al-Zawāj Fì Māliziyā." Masters diss., International Islamic University Malaysia, 2005.

Syamin, Rifqah Begum Mohammad. "Qaḍ̂yā al-Mahr Wa Hadāyā Fì Wilāyah Malākā." Masters diss., International Islamic University Malaysia, 2012. 